\title{
Lactic acid Production by a Mixed Culture of Lactic Bacteria Based on Low Value Dates Syrup and Their Metabolic Uses
}

\author{
Jacob Varghese B*, Khai Bui, Naomi Divall, Alexander Egan, Ali Kermani, Adam Lodge and Daniela Vollmer \\ Institute for Cell and Molecular Bioscience, Newcastle University, United Kingdom
}

\begin{abstract}
The common varieties of dates represent about $30 \%$ of national production. They are generally reserved for cattle feeding and sometimes thrown into the wild. Among these varieties, palm dates very rich in carbohydrates (glucose, fructose and sucrose) and contains practically most of minerals ( $\mathrm{Ca}, \mathrm{Fe}, \mathrm{K}, \mathrm{Na}$, etc.). The use of fermentation technology is necessary to save the genetic heritage and enhances by-product of dates in various bio products.

Lactic acid is a natural organic acid. The fermentation substrates most commonly used are glucose and fructose. The lactic acid has a major importance in food and pharmaceutical industries. It is used also in drink industries, medicines etc. Algeria till today continues to import this organic acid.

The objective of this study is the use of dates syrup as a substrate for the production of lactic acid, this study allowed us to have interesting results. Mixed culture of Streptococcus thermophilus and Lactobacillus bulgaricus, grown in batch fermentation. Two culture mediums were tested, the un-enriched one and the one enriched with Tween80 (1 g/l), $\mathrm{MgSO}_{4}(1 \mathrm{~g} / \mathrm{l}), \mathrm{MnSO}_{4}(1.5 \mathrm{~g} / \mathrm{l})$, from the results obtained by fermentation trials, the enriched medium seems best suited with a yield of lactic acid $49 \mathrm{~g} / \mathrm{l}$, where comes from its economical and commercial interest.
\end{abstract}

Keywords: Lactic acid; Streptococcus thermophilus; Lactobacillus bulgaricus; Date syrup; Fermentation; Metabolic rate

\section{Introduction}

Phoenicians heritage spreads on more than 85,000 hectors and reckons with more than 13 million palm trees, producing an average of 400,000 tons and allowing Algeria to the $5^{\text {th }}$ place among the world producers of dates [1].

The Phoenicians Algerian sector provides date varieties of high quality and excellent commercial value. Other varieties are less appreciated, less commercialized and less competitive, in return they are very rich in nutriments, sugars such as: glucose, fructose and sucrose, vitamins and minerals $[2,3]$. Subsequently, they provide a very high energy. The use of transformation technology shows that it's more necessary to use low-value dates for livestock feed [4].

Before adding the dates have subject of many tests in other contents. They are exploited as fermentation substrate for various metabolites production such as citric acid, ethanol and even biomass production (yeast bread) $[5,6]$.

Lactic acid or its derivatives are indeed widely used by the pharmaceutical industry, food processing and chemical industries for the synthesis of varnishes and plastics [7]. The biotechnology evolution and the integration of microbiology and biochemistry enabled to master fermentation techniques and processes by involving an appropriate substance for lactic acid production from molasses, carob and glucose [8].

The objective of this work consists to use a second quality date's syrup as a fermentation culture medium in the purpose of producing lactic acid by a mixed culture of Streptococcus thermophilus and Lactobacillus bulgaricus in different experimental conditions.

\section{Materials and Methods}

\section{Materials}

Vegetable material: The vegetable material used in current experiments was a half soft variety, known as palm dates badly exploited, cultivated in the area of Adrar (South-western of Algeria). The choice of this variety is justified by its availability and important nutritive value, especially the one of reducing sugars.
Biologic material: The biologic material used is cultures of Streptococcus thermophilus and Lactobacillus bulgaricus, derived from Orolait of Mascara (Algeria). The mixed culture is homofermentative (homolactic) which means that more than $90 \%$ of metabolites are produced by the lactic fermentation. The interest of mixed cultures of Streptococcus thermophilus and Lactobacillus bulgaricus is to start the phenomenon of symbiosis that is characterized by metabolic interactions between the two strains. This positive interaction demonstrated by comparing the lactic acid production in pure and mixed cultures of two species. The amount of lactic acid produced by the mixed culture is greater than the sum of acids produced by each of the pure cultures [9].

\section{Experimental protocol}

Preparation of date syrup: The dates are washed themselves, destoned and grounded. Two and half liters of hot water at $80-85^{\circ} \mathrm{C}$ were added to $1 \mathrm{~kg}$ of date, homogenized and through a cloth. The syrup obtained was centrifuged at $15000 \mathrm{rpm}$ for 10 minutes to separate the cellulose debris. The collected supernatant was used as culture medium. The syrup is sterilized during 20 minutes at $120^{\circ} \mathrm{C}$.

Batch fermentation: Batch cultures was performed in $250 \mathrm{ml}$ Erlenmeyer with a working volume of $100 \mathrm{ml}$, inoculated in the presence of MRS medium (Lactobacillus bulgaricus) and M17 medium (Streptococcus thermophilus) and incubated for $42 \mathrm{~h}$ at $85^{\circ} \mathrm{C}$, similar cultures were equally conducted in a reactor having a capacity of five liters provided with all the accessories. The temperature of fermentation

Corresponding author: Jacob Varghese B, Institute for Cell and Molecular Bioscience, Newcastle University, Richardson Road, Newcastle upon Tyne, NE2 4AX, United Kingdom, E-mail: vbjacob6@gmail.com

Received October 26, 2012; Accepted December 24, 2012; Published Decembe 26, 2012

Citation: Jacob Varghese B, Bui K, Divall N, Egan A, Kermani A, et al. (2012 Lactic acid Production by a Mixed Culture of Lactic Bacteria Based on Low Value Dates Syrup and Their Metabolic Uses. J Metabolic Synd 1:116. doi:10.4172/21670943.1000116

Copyright: (C) 2012 Jacob Varghese B, et al. This is an open-access article distributed under the terms of the Creative Commons Attribution License, which permits unrestricted use, distribution, and reproduction in any medium, provided the original author and source are credited. 
is maintained constant to $42^{\circ} \mathrm{C}$ and agitation is of 300 turns per minute. $\mathrm{pH}$ was fixed at 6.1 because the development of mixed culture needs a $\mathrm{pH}$ between 5.8 and 6.5).

The biomass evolution, sugar consumption and lactic acid production are followed at regular time intervals.

\section{Analytical methods}

Biochemical analysis: The content of water is determined by drying $10 \mathrm{ml}$ of syrup at $105^{\circ} \mathrm{C}$ for 18 hour [10]. The content of ashes is determined by incineration of one gram of syrup at a temperature of $600^{\circ} \mathrm{C}$ for 3 hours [11]. The reducing sugars, the sucrose and the total sugars were determined by the method of Bertrand, reported by Ikeda et al. [12]. The total nitrogen is determined by the method of Kreutzer et al. [13]. The mineral salts are determined according to the methods advocated by Nomikos et al. [14].

Kinetics of growth: We take off every two hours until 28 hours $10 \mathrm{ml}$ of medium of fermentation. We make a reading in a spectrophotometer to a length of wave $620 \mathrm{~nm}$.

Lactic acid: Concentration of the lactic acid was determined by acidity titration with $\mathrm{NaOH}[15]$.

Residual sugar: The content of residual sugar was determined by the method of Bertrand, reported by Ikeda et al. [9].

\section{Data processing}

The calculation of the kinetic parameters of fermentations has been performed using Kaleidagraph Software, is a specific program for the graphs, the histograms and of statistical calculation.

\section{Results and Discussions}

\section{Biochemical composition of syrup of dates}

The date syrup which has been the subject of our work has a high water content $88.69 \mathrm{~g} / \mathrm{l}$ (Table 1), we agree that a product with a high water content facilitates lactic acid bacteria proliferation and helps for a better substrate -enzyme contact since free water is the nutriments carrier, knowing that Lactobacillus bulgaricus needs a minimum water activity of 0.992 to grow while Streptococcus thermophilus needs a minimum of 0.983 .

Dates syrup will be very rich in sugars i.e. $56.8 \mathrm{~g} / \mathrm{l}$ among them a rate of $4.16 \mathrm{~g} / \mathrm{l}$ for sucrose [16]. It indicates the grade of $84 \mathrm{~g} / \mathrm{l}$ of

\begin{tabular}{|l|c|}
\hline Constituants & Date syrup \\
\hline Content in water in percentage & 88.69 \\
\hline $\mathrm{pH}$ & 5.9 \\
\hline Total sugars in percentage of M.F & 56.8 \\
\hline Reducing sugars in percentage of M.F & 26.8 \\
\hline Sucrose in percentage of M.F & 4.16 \\
\hline Proteins in percentage of M.F & 1.02 \\
\hline Ashes in percentage of M.F & 0.9 \\
\hline Potassium in $\mathrm{mg} / 100 \mathrm{ml}$ of M.F & 280 \\
\hline Phosphor in $\mathrm{mg} / 100 \mathrm{ml}$ of M.F & 28 \\
\hline Sodium $\mathrm{mg} / 100 \mathrm{ml}$ of M.F & 180 \\
\hline Calcium in $\mathrm{mg} / 100 \mathrm{ml}$ of M.F & 146 \\
\hline Zinc in $\mathrm{mg} / 100 \mathrm{ml}$ of M.F & 0.19 \\
\hline Copper in $\mathrm{mg} / 100 \mathrm{ml}$ of M.F & 0.17 \\
\hline Magnesium in $\mathrm{mg} / 100 \mathrm{ml}$ of M.F & 0.11 \\
\hline Manganese in $\mathrm{mg} / 100 \mathrm{ml}$ of M.F & 0.19 \\
\hline
\end{tabular}

Table 1: Biochemical composition of syrup of dates.

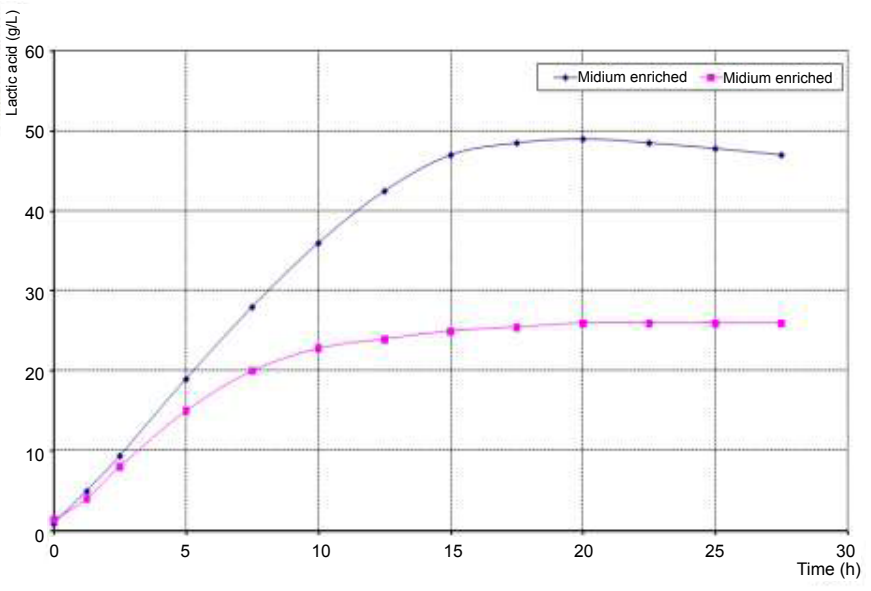

Figure 1: Evolution of lactic acid rate produced by both fermentations.

total sugars in the soluble extract of date's syrup. These differences are explained by climatic variations. Reducing sugars are a carbon source that can satisfy the ferments requirements.

The protein fraction is considerable; therefore it can serve as a nitrogen source. An ash content of $0.9 \mathrm{~g} / \mathrm{l}$ indicates its richness of minerals including potassium (280), sodium $(180 \mathrm{mg} / 100 \mathrm{ml}$ of MF), phosphorus ( $28 \mathrm{mg} / 100 \mathrm{ml}$ of MF) and calcium ( $146 \mathrm{mg} / 100 \mathrm{ml}$ of MF) and a very small amount of magnesium $(0.11 \mathrm{mg} / 100 \mathrm{ml}$ of MF) and manganese $(0.19 \mathrm{mg} / 100 \mathrm{ml}$ of $\mathrm{MF})$.

The date's syrup has an acidic pH 5.9 close to neutrality which indicates its good nutritional quality (no bacterium contamination) suitable for the proper development of lactic acid bacteria. Similarly Ikeda [17] stated that the majority of common varieties (dates of average quality) have $\mathrm{pH}$ ranging between 5.3 and 6.3 .

The analysis applied on the date syrup shows that it is poor, with minerals such as Magnesium, Manganese and fatty-acids, so the addition of these elements (growth factors) is necessary to the syrup in order to import this quantity of lactic acid.

Finally, the biochemical analysis of date's syrup shows that it can constitute a fermentation medium of good quality.

\section{Results of the fermentation kinetics}

The production curves of lactic acid in enriched and un-enriched mediums looked the same, the production in the un-enriched begins with an initial rate of $0.12 \mathrm{~g} / \mathrm{l}$ to achieve $26 \mathrm{~g} / \mathrm{l}$ of lactate in $28 \mathrm{~h}$ of fermentation (Figure 1). In parallel, in the medium enriched with Tween80, $\mathrm{MgSO}_{4}$ and $\mathrm{MnSO}_{4}$, the lactic acid rate evolves gradually to achieve the end of fermentation $49 \mathrm{~g} / \mathrm{l}$.

Meanwhile, the biomass evolution in the enriched medium starts with an initial concentration $(\mathrm{OD}=0.04)$ and after $28 \mathrm{~h}$ of fermentation it reaches a maximum value $(\mathrm{OD}=2.40)$ (Figure 2). In the case of nonenriched one we observe a low initial concentration of biomass and in the end of fermentation optical density reaches a maximum value 1.15.

However, decreasing of sugar rates is very faster in the medium supplemented with $\mathrm{MgSO}_{4}, \mathrm{MnSO}_{4}$ and Tween80. Where the mixed culture consumes about half quantity of initial total sugars, during $28 \mathrm{~h}$ of fermentation from an initial quantity of $56.8 \mathrm{~g} / \mathrm{l}$ of sugars, it remains $31.3 \mathrm{~g} / \mathrm{l}$ which implies an amount of $25.5 \mathrm{~g} / \mathrm{l}$ (Figure 3). In parallel 11.7 $\mathrm{g} / \mathrm{l}$ as the quantity of sugar consumed in non-enriched medium. 


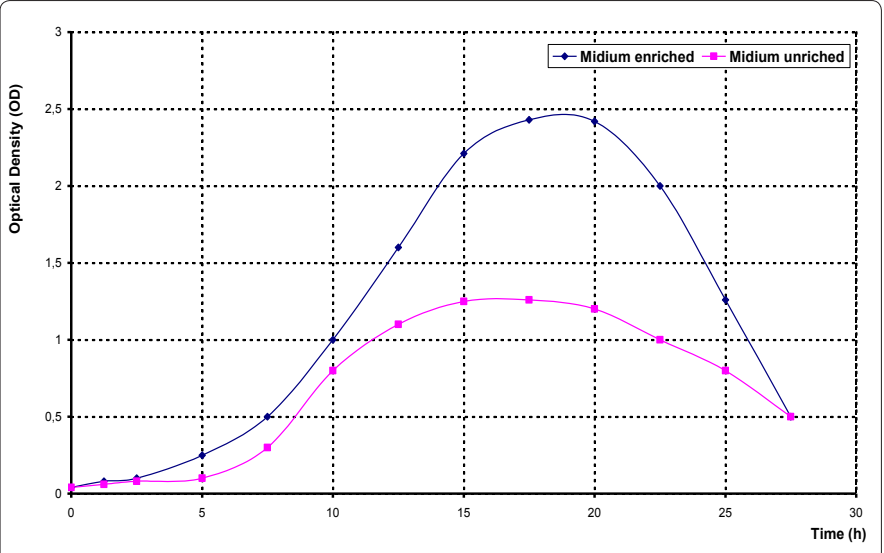

Figure 2: Evolution of optical density for both fermentations during time.

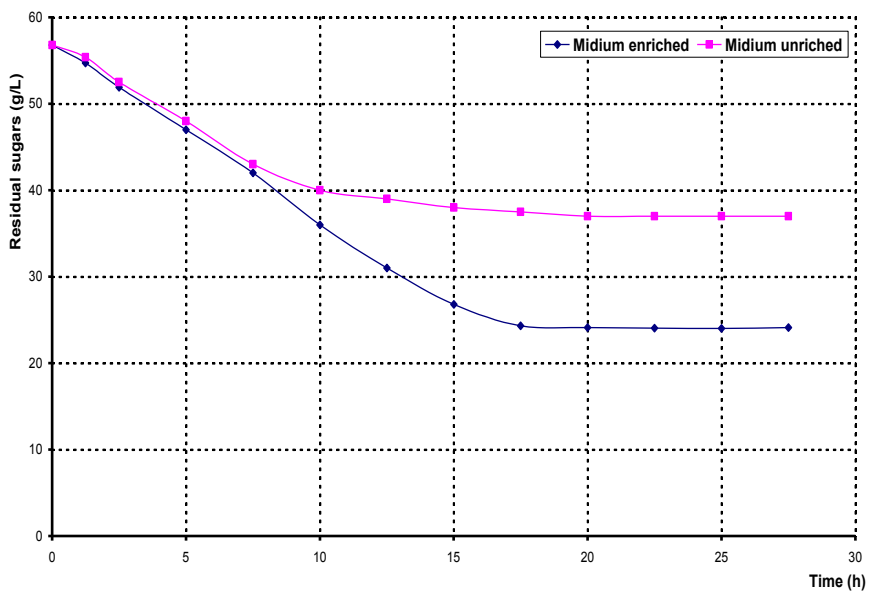

Figure 3: Evolution of residual sugars rate for both fermentations during time.

Comparing the results for both fermentations indicated that the addition of growth factors in culture medium has a positive and beneficial effect on fermentation, since the growth rate and lactic acid production increase after the enrichment of date syrup.

According to Nomikos et al. [14], the addition of Tween 80 allows better cells excretion of lactate by creating pores in the membrane and plays the role of surfactant which makes a good contact between seed and nutriments, and for more it is considered as a source of carbon and energy for electrons.

According to Beauregard et al. [15], the presence of manganese in the medium is specific and cannot be replaced by other minerals, because the $\mathrm{Mg}^{++}$enters in the structure and functioning of enzymes.

By the same author, the addition of Manganese stimulates the proliferation of Streptococcus thermophilus and it is essential also for Lactobacillus bulgaricus, as $\mathrm{Mn}^{++}$is the activator of various metabolic reactions, it participates in the transfer of lactate across the cytoplasmic membrane to be released in the medium.

From these results, the enriched medium seems the best for its interesting results. Indeed, a production of $49 \mathrm{~g} / \mathrm{l}$ of lactic acid obtained with medium based on date syrup enriched with Tween 80 , $\mathrm{MgSO}_{4}$ and $\mathrm{MnSO}_{4}$ is higher comparing to the results found by Ikeda et al. [18].

\section{The kinetic parameters of fermentation}

Changes over time of specific growth rates $(\mu)$, lactate production $\left(\mathrm{Q}_{\mathrm{L}}\right)$ and substrate consumption $\left(\mathrm{Q}_{\mathrm{S}}\right)$ are presented in figures 4-6.

In unenriched medium, the specific growth speed $(\mu)$ after 3 hours of fermentation is 0.38 per hour (Figure 4 ). For the culture enriched with Tween80, $\mathrm{MgSO}_{4} \mathrm{MnSO}_{4}$ the specific growth rate begins with a top speed of $1 \mathrm{~h}^{-1}$ then decreases with time to the point of cancellation, which corresponds to 18 hours of culture time.

Basing on these results, we can say that the earlier addition of manganese, magnesium and Tween 80 in fermentation helps in improving culture, enhancing and promoting cell proliferation and metabolic reactions. The decreasing in specific growth rates in the two fermentations can be explained by the disappearance of the culture medium, one or more essential elements to the maintenance and cell growth, it can be due also to the realizing of culture medium by using substances that have been fatal for the growth; this causes despite the abundance of sugar (carbon source) cell lyses and death of cells.

Specific speed of sugar consumption is very important $16 \mathrm{~g} / \mathrm{g}$. h in un-enriched fermentation, whereas it is $7 \mathrm{~g} / \mathrm{g}$. $\mathrm{h}$ for fermentation supplemented with Tween80, $\mathrm{MnSO}_{4}$ and $\mathrm{MgSO}_{4}$ (Figure 5). This is logical since the maximum amount of biomass obtained for the first fermentation does not exceed $1 \mathrm{~g} / \mathrm{l}$, and to calculate this rate we divide the changes of consumed sugar by biomass variation.

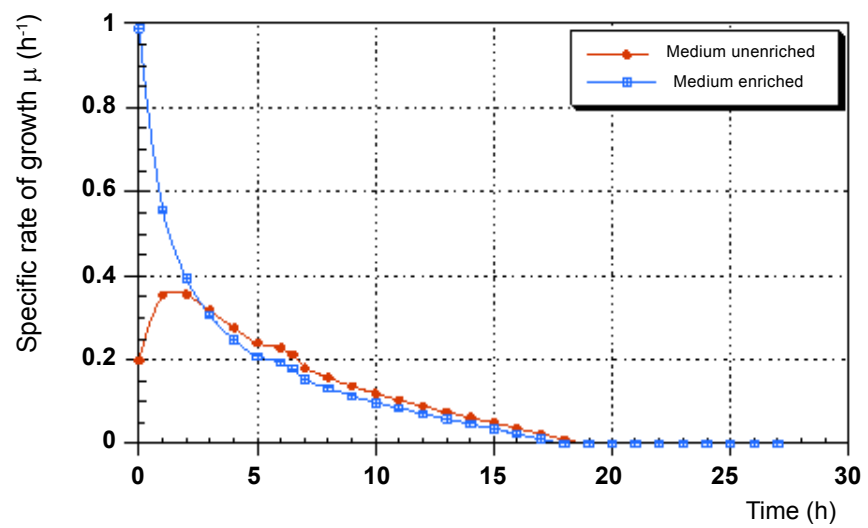

Figure 4: Evolution of specific growth rates $(\mu)$ for both fermentations during time.

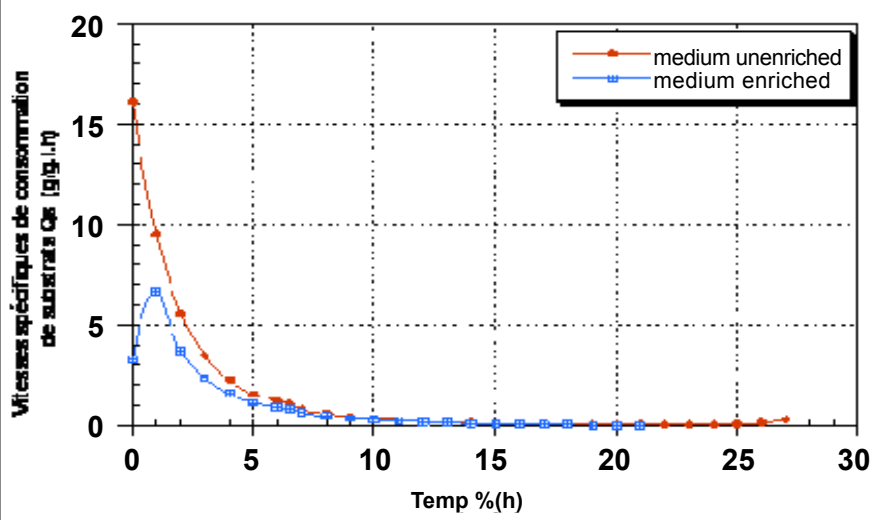

Figure 5: Evolution of specific rates of sugar consumption $\left(Q_{s}\right)$ for both fermentations during time. 
Citation: Jacob Varghese B, Bui K, Divall N, Egan A, Kermani A, et al. (2012) Lactic acid Production by a Mixed Culture of Lactic Bacteria Based on Low Value Dates Syrup and Their Metabolic Uses. J Metabolic Synd 1:116. doi:10.4172/2167-0943.1000116

Page 4 of 4

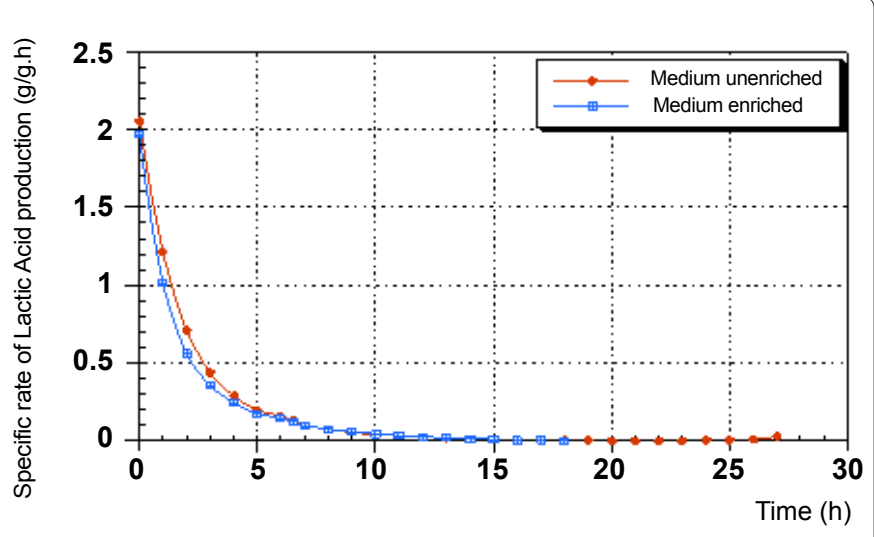

Figure 6: Evolution of specific speeds of lactic acid production $\left(Q_{L}\right)$ for both fermentations during time.

After a time of fermentation, the specific rates of sugars consumption for both fermentations start to decline and to be cancelled after 18 hours of fermentation, which correspond to cells death described above.

Specific speeds of lactic acid production in the two fermentations give identical and maximum values of $2 \mathrm{~g} / \mathrm{g}$. h (Figure 6), they are superimposed and decline together to be cancelled after 18 hours of fermentation.

\section{Conclusion}

The bioconversion of agricultural by- products mainly the ones rich in fermentable sugars has an economic and strategic interest.

By its biochemical composition, the date's syrup is very rich in carbohydrates $56.8 \mathrm{~g} / \mathrm{l}$. which make it a substrate of choice for the development of high value substances.

The kinetics of growth under our experimental conditions showed that the date's syrup is a growing medium that induces the biosynthesis and production of lactic acid in two lactic mixed cultures of Lactobacillus bulgaricus and Streptococcus thermophilus. The results obtained from the fermentation trials show that the mixed culture can produce $26 \mathrm{~g} / \mathrm{l}$ of lactic acid in medium based on date's syrup. This medium requires an addition of Magnesium, Manganese and Tween 80 to allow an adequate growth and maximum production of lactic acid $49 \mathrm{~g} / \mathrm{l}$.

At the end of this study, it appears that the valuation of date's syrup by biological means (fermentation) for the production of lactic acid has certainly huge advantages.

\section{References}

1. Ben-Shlomo A, Melmed S (2008) Acromegaly. Endocrinol Metab Clin North Am 37: 101-122.

2. Baldys-Waligorska A, Krzentowska A, Golkowski F, Sokolowski G, HubalewskaDydejczyk A (2010) The prevalence of benign and malignant neoplasms in acromegalic patients. Endokrynol Pol 61: 29-34.

3. Brooke AM, Drake WM (2007) Serum IGF-levels in the diagnosis and monitoring of acromegaly. Pituitary 10: 173-179.

4. Colao A, Ferone D, Marzullo P, Lombardi G (2004) Systemic complications of acromegaly: epidemiology, pathogenesis, and management. Endocr Rev 25: 102-152.

5. Bergstrom M, Muhr C, Lundberg PO, Langstrom B (1991) PET as a tool in the clinical evaluation of pituitary adenomas. J Nucl Med 32: 610-615

6. Chanson P, Salenave S, Kamenicky P, Cazabat L, Young J (2009) Pituitary tumours: acromegaly. Best Pract Res Clin Endocrinol Metab 23: 555-574.
7. De Souza B, Brunetti A, Fulham MJ, Brooks RA, DeMichele D, et al. (1990) Pituitary microadenomas: a PET study. Radiology 177: 39-44.

8. Peterson OF, Esperson JO (1984) Extradural hematomas: measurement of size by volume summation on CT scanning. Neuroradiology 26: 363-367.

9. Ikeda H, Abe T, Watanabe K (2010) Usefulness of composite methioninepositron emission tomography/3.0-tesla magnetic resonance imaging to detect the localization and extent of early-stage Cushing adenoma. J Neurosurg 112 750-755.

10. Losa M, Oeckler R, Schopohl J, Muller OA, Alba-Lopez J, et al. ( 1989) Evaluation of selective transsphenoidal adenomectomy by endocrinological testing and somatomedin-C measurement in acromegaly. J Neurosurg 70 561-567.

11. Giustina A, Barkan A, Casanueva FF, Cavagnini F, Frohman L, et al. (2000) Criteria for cure of Acromegaly: A consensus statement. J Clin Endocrino Metab 85: 526-529.

12. Ikeda H, Jokura $H$, Yoshimoto $T$ (2001) Transsphenoidal surgery and adjuvant gamma knife treatment for growth hormone-secreting pituitary adenoma. J Neurosurg 95: 285-291.

13. Kreutzer J, Vance ML, Lopes MB, Laws ER Jr (2001) Surgical management of $\mathrm{GH}$-secreting pituitary adenomas: an Outcome study using modern remission criteria. J Clin Endocrinol Metab 86: 4072-4077.

14. Nomikos P, Buchfelder M, Fahlbusch R (2005) The outcome of surgery in 668 patients with acromegaly using current criteria of biochemical 'cure'. Eur J Endocrinol 152: 3790-387.

15. Beauregard C, Truong U, Hardy J, Serri O (2003) Long-term outcome and mortality after transsphenoidal adenomectomy for acromegaly. Clin Endocrino (Oxf) 58: 86-91.

16. Bonneville JF, Bonneville F, Cattin F ( 2005) Magnetic resonance imaging of pituitary adenomas. Eur Radiol 15: 543-548

17. Ikeda H (2011) Diagnosis of Cushing's disease in Berhardt LV (ed), Advances in Medicine and Biology. New York: Nova Science Publishers.

18. Ikeda H, Sato S, Saginoya S, Watanabe K ( 2011) MET-PET images of patients with abnormal GH secretary dynamics. Endocr Pathol 23: 70-71. 